\title{
Effect of Educational Program on Nurses' practice Regarding Care of Adult Patients with Endotracheal Tube
}

\author{
Amira Mohammed Ali Hassan RN ${ }^{1}$, Magda Mohamed Abd El-Aziz RN, PhD ${ }^{2}$, \\ Manal Salah Hassan RN,PhD², Wafaa Abd El-Azeem EL-hosany RN, PhD ${ }^{3 .}$ \\ Assistant lecturer Medical-Surgical Nursing, Faculty of Nursing -Suez Canal \\ University, Professor of Medical Surgical Nursing, Faculty of Nursing, Ain-Shams \\ University, Assistant professor of Nursing Administration, Faculty of Nursing -Suez \\ Canal University
}

\begin{abstract}
The majority of patients admitted to Intensive Care Unit (ICU) requiring endotracheal intubation to maintain oxygenation and ventilation. Aim: to study the effect of educational program on nurses' practices regarding care of adult patients with endotracheal tube. Methods: A quasi-experimental design was used on a convenience sample of all available nurses (50 nurses) who were working in Intensive Care Unit, Cardiac Care Unit and Cardiothoracic Care Unit at Suez Canal University Hospital. Two tools were developed by the researcher for data collection including observational checklists regarding endotracheal tube care and nurses' opinionaire regarding the educational program. Results: there were highly statistically significant differences in total nurses' practice regarding care of patient with endotracheal tube during all program phases. Conclusion: the educational program improves nurses' practice regarding caring adult patients with endotracheal tube. Recommendations: the importance of presence of protocol or guidelines related to patients' care with endotracheal tube and upgrading nurses' practice about caring of patients with endotracheal tube through attending seminars and workshops about endotracheal tube care.
\end{abstract}

Key words:-Endotracheal intubation (ETI), Educational program, Nurses' practice. 


\section{INTRODUCTION}

Intubation in the critically ill patient with difficult airway in emergency and planned intubations (e.g., scheduled surgery or invasive procedures) are associated with complication as cardiovascular collapse and hypoxemia thus frequent preoxygenation techniques and entertained intubation procedures to avoid and reduce the occurrence of life-threatening problems subsequent intubation (De Jong et al., 2014).

There were two routes of endotracheal intubation oral and nasal intubation. Firstly, oral intubation (orotracheal intubation) the ET tube passed visually through the mouth, vocal cords and into trachea with aids of laryngoscope or bronchoscope by trained respiratory therapist ,nursing and medical personal; whereas the secondly, nasal ET intubation (nasotracheal intubation) endotracheal tube is placed blindly through the nose, nasopharynx, and vocal cord till trachea. Moreover, oral ET intubation is the most and best method in emergencies because airway can be secured rapidly ( Proehl, 2009 and Lewis et al., 2014).

Advantages of oral intubation can be summarized in: Firstly, it can be simply inserted; secondly, it allows larger endotracheal tube for insertion, while disadvantage uncomfortable, less stable, gag reflex stimulation, chewed or biting ETT, it increases secretion in mouth and contraindicated in cervical cord injury. On the other hand, advantage of nasal intubation include allowing oral hygiene easily and more comfortable during insertion, moreover there are many disadvantage for nasal intubation as difficult ETT insertion, sinus necrosis may occur, necessitate small tube size and can be contraindicated for patient with obstructed nose, basal skull fracture and hemorrhagic disorder (Dennison, 2013 and Aitken et al., 2016).

Despite ETT is potentially considered life-saving technique, the presence of an endotracheal tube (ETT) is a significant stressful event and may cause considerable discomfort to intensive-care patients (Samuelson, 2011). The most common complications accompanying endotracheal tube insertion which need special care around 24-hour such as: hypercapnia, hypoxemia, laryngospasm, bronchospasm, VAP, fractured teeth, aspiration of oral or gastric contents, displacement of tube, laryngeal 
damage, necrosis, tracheal stenosis, herniation of cuff through vocal cords, otitis media, inflamed lips mentioned by (Morton \& Fontaine, 2013 and Bahar et al., 2015).

The nurse plays crucial role for caring patients with ETT as monitoring respiratory status and placement of the endotracheal, providing oral care every 2 hours and repositioning the client to avoid threats of immobility (e.g. pneumonia). In addition to performing ETT suctioning of secretions from lung which patients are unable to mobilize (Morton \& Fontaine, 2013).

The health educational programs are designed to meet the health needs or problem in population. Generally, these programs involve educating individual members of population about health promotion, illness prevention and treatment (American Nurse Association "ANA", 2011). Nursing programs are outcomes of dynamic relationship with social, educational, economical, legislative and professional forces present in contemporary society. Nurses' education has major role in ensuring that nursing practice is relevant, sensitive and capable of responding to the mode range of health and social need of society (Cherry \& Jacob, 2016).

\section{Significance of the Study:}

Incorrect management of endotracheal tube may lead to a number of complications, which can result in increased morbidity, extended hospitalization, and in some cases mortality. Thus nurses should have practice to give care of patients and provide timely intervention to minimize the associated problems and complications during caring of patients with endotracheal tube. In Egypt, Omera et al., (2013) found that there is a serious lack of nurses practice regarding care provided for patient with endotracheal tube, so that this study focuses on improving nurses' practice through implementing an educational program regarding care of adult patients with endotracheal tube.

\section{THE AIM OF THE STUDY:}

To study effect of educational program on nurses' practices regarding care of adult patients with endotracheal tube.

\section{The aim of study achieved through the following objectives}

- Assess Nurses' practice regarding care of adult patients with endotracheal tube. 
- Develop an educational program based on nurses' need regarding care of adult patients with endotracheal tube.

- Implement an educational program on nurses' practice regarding care of adult patients with endotracheal tube.

- Evaluate the effect of educational program on nurses' practice regarding care of adult patients with endotracheal tube.

\section{Research Hypothesis:}

The practice scores of nurses after exposing to an educational program will be higher than before.

\section{SUBJECTS AND METHODS}

\section{Research Design:}

A quasi-experimental design was used to achieve the aim of the study.

\section{Study setting}

The study was conducted at Suez Canal University Hospital in Ismailia City at Intensive Care Unit, Cardiothoracic Care Unit and Cardiac Care Unit.

\section{Subjects}

Convenience sample of all available nurses (50 nurses) were working in the previous mentioned settings. Nurses' age was ranged between 20-35 years old; years of experience were ranged between 1-15 years and nurse's education level was either diploma degree (19) or technical institute degree (31).

\section{Tools of Data Collection}

Data were collected by using two tools.

\section{Tool (1): Endotracheal tube care observational checklist}

The researcher used observational checklists to assess nurses' practice regarding endotracheal tube care which adapted from (Lynn, 2015a; Delaune \& Lander, 2011 and Perry \& Potter, 2010).

\section{Two observation checklists as:}

1. Observational checklist regarding endotracheal tube suctioning and oral care. 
- Observational checklist regarding endotracheal tube securing and ETT cuff pressure measuring. After that the researcher used this tool in (Pre - post \& follow up).

- First observational checklist consists of preparation of ETT suctioning and oral care (15 steps); procedure of ETT suctioning and oral care (24 steps); post procedure of ETT suctioning \& oral care (8 steps) and documentation after performing the procedure ( 8 steps).

- Second observational checklist consist of preparation of securing and measuring cuff pressure of ETT (13 steps); Procedure of securing of ETT (10 steps); Securing Trachy method \& Tape method (18 steps); measuring ETT cuff (7 steps) pressure; post securing procedure of ETT of measuring ETT cuff pressure (6 steps) and documentation after performing the procedure of securing $\&$ measuring cuff pressure of ETT (6 steps).

\section{Scoring System:}

Each step in the observational checklist was checked as done and not done practice. The total score of all practices were 174 grades ( 87 steps). The step done was taken (2); while the step not done take scoring (1). The total score of all practice classified as the following

$<75 \%$ was considered unsatisfactory.

$\geq 75 \%$ was considered satisfactory

\section{$\underline{\text { Tool II }}$}

- Nurses' opinionaire regarding the educational program:

It was developed by the researcher used to assess nurses' opinions regarding using educational program. It was designed in a simple Arabic language to facilitate understanding and to minimize misconception.

- Scoring system stated according the nurses' opinions as excellent or very good or good or passes. 


\section{Methods of study}

- An official permission for data collection in Suez Canal University Hospital was obtained from the hospital administrative personnel by submission of a formal letter from the vice dean of the faculty of nursing, Suez Canal University.

- The tool was tested for their content validity and clarity by 9 expertises in nursing and ICU and anesthesiology department then appropriate modification was done accordingly.

- Informed consent was obtained from each nurse in the study after explaining its purpose and importance. Confidentially of the information was assured by the researcher.

- A pilot study was carried out after the development of the tools. It was carried out on $10 \%$ (7 Nurses) of the nurses working in intensive care unit, cardiothoracic care unit and coronary unit at Ismailia University Hospital to test the reliability and applicability of the tools of the study. The necessary modification was done based on the results of the pilot study. These nurses were excluded from the subject of research work to assure the stability of answers.

- The actual study was conducted through four phases: assessment phase, program development phase, implementation phase and evaluation phase.

\section{Content reliability}

It was established by Split-Half Reliability used Spearman -Brown and Guttmann split half reliability to measure internal consistency of tools (reliability of the used tool or instrument). These showed high reliability score for the following:

- $\quad$ Nurses' questionnaire $=0.903$

- Observational checklist $\mathrm{A}=0.874$

- Observational checklist $\mathrm{B}=0.909$

\section{Phase I (Preparatory phase):}

Teaching materials were prepared as audiovisual materials, and handouts. To assess nurses' practice regarding care of patients with endotracheal tube through observing their practice through observational checklist the sheet (Tool I) .

(Tool II) done after finishing the program to identify nurses' opinionaire regarding the educational program. 


\section{Educational program:}

An educational program on nurses' practice regarding care of adult patients with endotracheal tube

\section{A-Formulation of objective:-}

The aim of the program was study the effect of educational program on nurses' practice regarding care of adult patients with endotracheal tube.

B- Contents: covered all areas regarding care of adult patients with endotracheal tube include: endotracheal suctioning, oral care, securing and measuring cuff pressure of ETT.

\section{Program description:}

The program designed to be practical in nature addressing knowledge necessary for caring adult patients with endotracheal tube. The program construction gone through the following phases:

\section{Pre-planned phase include:}

A. The frame work for the program

B. Setting of the program, general objectives.

C. Allocation of the program resources and facilities (setting and printed materials).

D. Constructed of evaluation device to measure the program effectiveness (pre/ post and follow- up nurses' self-structured questionnaire and nurses' opinions sheet about program.

\section{Planning phase includes:}

- Determine the program strategies (timetable sessions, teaching methods, media used, learners 'activities and evaluation methods, selecting the teaching place (nurses' working unit), the program finances (supplied by the researcher such as all printing and material media), the learning objectives of the program, learner characteristics, the learning content of the program, the teaching methods and media and the evaluation methods.

\section{Phase II (Implementation):}

Permission to conduct the study obtained from the responsible authorities (in Suez Canal University Hospital was obtained from the hospital administrative personnel by 
submission of a formal letter from the vice dean of the Faculty of Nursing, Suez Canal University) after the explanation of its purpose and nature of study.

The implementation of training program was covered over small sessions, including theoretical content developed and selected based on the identified needs and demands of nurses which gathered in phase I, and in the light of the most recent pertinent literature.

The nurses divided into three groups according to their working units. The training program will be implemented for each group of nurses in their unit. The program presented in clear and concise form and focused on the point of learning using different teaching methods as discussion group, lecture by using suitable teaching aids for the program such as handout, posters, colored picture and program booklet was developed and distributed to all nurses.

\section{The program was implemented through the theoretical session:}

\section{A. Practical session included (four sessions):}

○ ETT suctioning.

- Oral care.

○ ETT securing or re-taping.

- ETT cuff pressure measuring.

\section{Phase III (Evaluation):}

Evaluation the nurses' practice was done immediately post as well as after 3 months of program implementation. The follow -up was done to assess nurses' practice regarding care of patient with endotracheal tube through analysis the data and comparing the results of pre/ post and follow -up phase to assess effectiveness of program.

\section{Ethical Considerations:}

The agreement for nurses participating of the subjects was taken after the study aims had been explained to them; they were given an opportunity to refuse to participate, and they were assured that the information collected would be treated confidentially and used for the research purpose only. Also nurses' oral consent was obtained before starting data collection. 


\section{Statistical design:}

At the end of the fieldwork, data sets obtained in different body postures were coded and transformed into coding sheets. The results were checked. Then, the data were entered into SPSS system files (SPSS package version 18) using personal computer. Output drafts were checked against the revised coded data for typing and spelling mistakes. Finally, analysis and interpretation of data were conducted.

\section{The following statistical measures were used:}

- Descriptive statistics including frequency, distribution, range, mean and standard deviation were used to describe different characteristics.

- Kolmogorov - Smirnov test was used to examine the normality of data distribution.

- Univariate analyses including: Student t-test and ANOVA test were used to test the significance of results of quantitative variables. Paired t-test was used to test the significance of results of paired quantitative variables at different timing of the study. Also, Mac Nemar test was used to test the significance of results of paired qualitative variables.

- The significance of the results was at the 5\% level of significance.

\section{Limitation of the Study:}

The studied nurses were not available all together at the same time; so the researcher had to get them during their shifts to complete the questionnaire sheet. Also after start program and do pre -program and after program implementation through immediate post program some of nurse leave the hospital or have Maternity Leave or transport to other hospitals. This decrease nurses number from 70 to 50 nurses through implementing program.

\section{RESULTS :}

Table (1): showed the demographic characteristics of the studied nurses. Regarding nurses' age, it was showed that $60 \%$ (30) of the studied nurses were twenty years old to less than twenty five years old, While 64\% (32) of studied nurses were female. In relation to qualifications, it was showed that $62 \%$ of the studied nurses have been graduated from a nursing technical institute. Moreover, it was clear that equal percentages of studied nurses $30 \%$ working in Cardiac Care Unit \& Cardio-thoracic 
Care Unit and $40 \%$ of studied nurses working ICU. Regarding the nurses' years of experience, it was showed that $42 \%$ of them ranged from one year to less than five years. Also, $62 \%$ of them have had training courses regarding endotracheal tube care.

Figure (1): this figure clarified the precentages distrubation of studied nurses benefits from training course on endotracheal tube care, it was showed that $68 \%$ them had gained moderate benefits, $29 \%$ of them have gained high benefits and only $3 \%$ of them had low benefits.

Figure (2): this figure clarified the precentage distribution of the presence of guidance about endotracheal tube care, it was showed that $80 \%$ of the studied nurses notified that they had never receive guiadance related to endotracheal tube care in their units

Figure (3): this figure clarified the total nurses' practices scores regarding care of patients with endotracheal tube during program phases. It was showed that all nurses' had unsatisfactory practices through pre program while, $96 \%$ of them had satifactory practices during post program as well as $88 \%$ of them had satisfactory practices at follow- up phase.

Table (2): this table showed that there was a highly statistically significant difference for total score of nurses' practices in all program phases at $\mathrm{p}<0.0001$, as well as there was a highly statistically significant difference for total practice score of nurses related to securing and measuring ETT cuff pressure at $\mathrm{p}<0.0001$.

As regarding to total score of nurses' practice during suctioning and oral care, there was a highly statistically significant difference during pre/post program and pre/follow-up program at $\mathrm{p}<0.0001$ while there was no statistically significant difference in post/follow up program phase.

Table (3): represented frequency and percentage distribution of the total score of nurses' practice related to endotracheal tube suctioning and oral care throughout the program intervention phases. There was a highly statistically significant difference in total score of nurses' practice in pre/ post and pre/follow-up program implementation 
phases at $\mathrm{P}<0.0001$, while there was no statistically significant difference in total score of nurses' practice in post/follow-up program phases.

Table (4): represented the differences in the total scores of nurses' practice regarding securing and measuring cuff pressure of endotracheal tube through program phases. There was a highly statistically significant difference in total score of nurses' practices in securing and measuring cuff pressure of endotracheal tube in pre/ post and pre/follow-up program implementation phases at $\mathrm{P}<0.0001$, while there was no statistically significant difference in total score of nurses' practices in securing and measuring cuff pressure of endotracheal tube in post/follow-up program implementation phases.

Table (5): showed the comparison between mean score of studied nurses' practice related to care for patients with endotracheal tube throughout the program intervention according to their characteristics. There was only one statistically significant difference found between practice of studied nurses and their department of employment $(\mathrm{P}=0.013)$ in favor of intensive care unit nurses which had the highest means in followup program implementation that showed: Mean \pm SD $(96.4 \pm 2.7)$.

Table (6): This table illustrated that $84 \%$ of nurses stated that the topic of the program was excellent; while all nurses $(100 \%)$ clarified that the scientific content was excellent. With regard to the benefit of the program, $82 \%$ of the studied nurses stated that it was excellent.

Table (7) showed that as regarding to method of teaching $52 \%$ of the studied nurses stated that using lecturer and demonstration \&re-demonstration were very good respectively. In addition to all of the studied nurses (100\%) stated that using poster and booklet were excellent respectively. 
Table (1): Frequency and percentage distribution of demographic characteristics of studied nurses $(\mathrm{n}=50)$.

\begin{tabular}{|c|c|c|}
\hline \multirow[t]{2}{*}{ Demographic characteristics } & \multicolumn{2}{|c|}{$\begin{array}{l}\text { Studied nurses } \\
\qquad(\mathrm{n}=\mathbf{5 0})\end{array}$} \\
\hline & No. & $\%$ \\
\hline \multicolumn{3}{|l|}{ Age (years) } \\
\hline 20 & 2 & 4.0 \\
\hline $20-<25$ & 30 & 60.0 \\
\hline $25-<30$ & 15 & 30.0 \\
\hline $30+$ & 3 & 6.0 \\
\hline \multicolumn{3}{|l|}{ Gender } \\
\hline Female & 32 & 64.0 \\
\hline Male & 18 & 36.0 \\
\hline \multicolumn{3}{|l|}{ Qualifications } \\
\hline Diploma nursing & 19 & 38.0 \\
\hline Technical Nursing institute & 31 & 62.0 \\
\hline \multicolumn{3}{|l|}{ Work place } \\
\hline ICU & 20 & 40.0 \\
\hline Cardiac Care Unit & 15 & 30.0 \\
\hline Cardio-thoracic Care Unit & 15 & 30.0 \\
\hline \multicolumn{3}{|l|}{ Years of nursing experience } \\
\hline$<1$ & 5 & 10.0 \\
\hline $1-<5$ & 21 & 42.0 \\
\hline $5-<10$ & 19 & 38.0 \\
\hline $10+$ & 5 & 10.0 \\
\hline \multicolumn{3}{|l|}{ Previous training regarding ETT care } \\
\hline No & 19 & 38.0 \\
\hline Yes & 31 & 62.0 \\
\hline
\end{tabular}




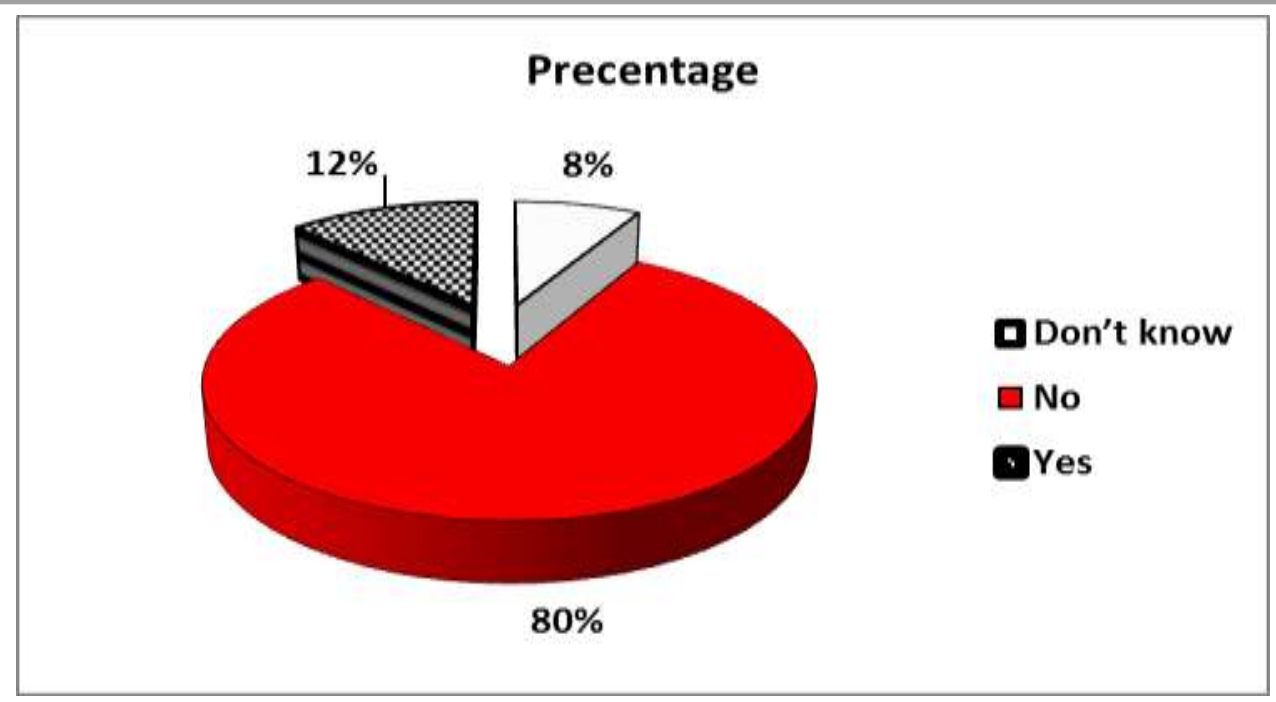

Figure 1: Precentages distrubation of studied nurses' benefits from training course regarding endotracheal tube care

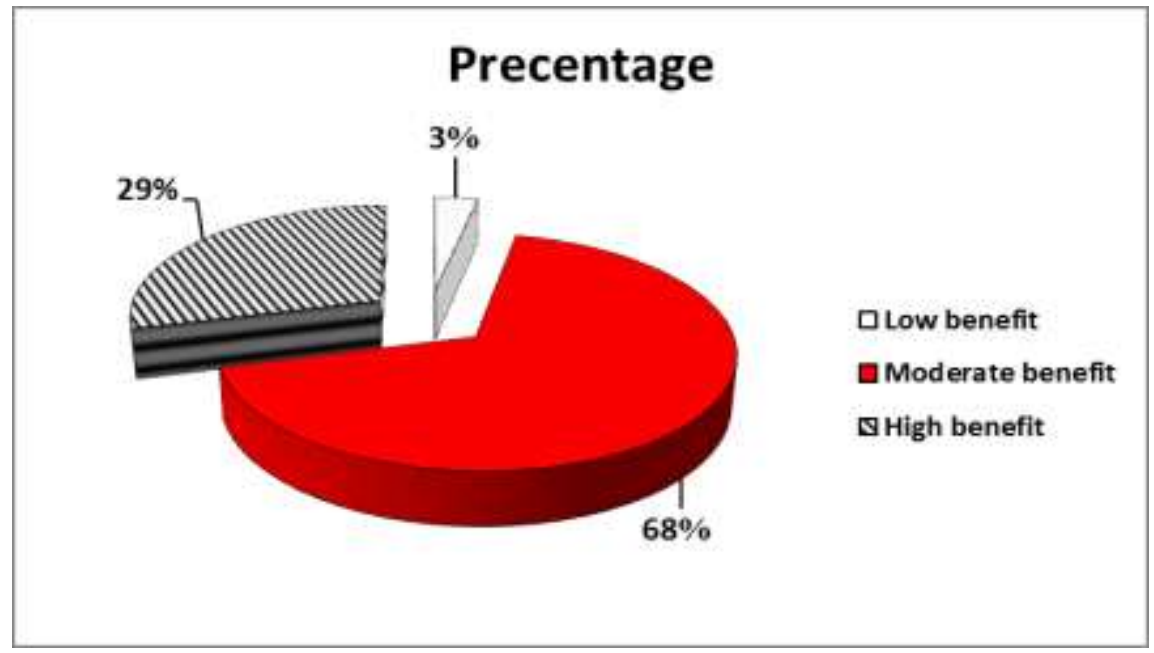

Figure 2: Precentage distribution of the presence of guidance about endotracheal tube care

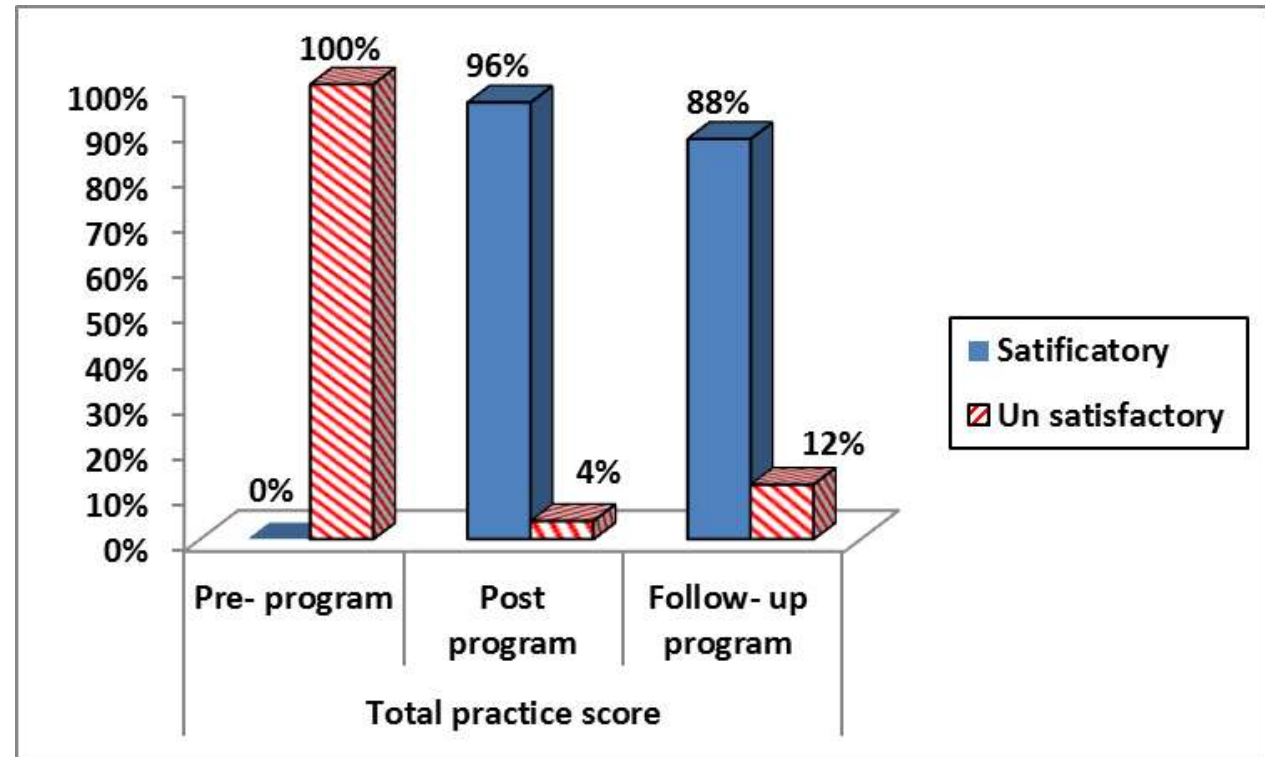

Figure 3: Total nurses' practices score regarding care of patients with endotracheal tube during program phases. 
Table (2): Mean scores for nurses' practice regarding endotracheal tube care pre/ post implementation of educational program and after follow-up phases $(n=50)$

\begin{tabular}{|c|c|c|c|c|c|c|}
\hline \multirow[b]{2}{*}{ Practice } & \multicolumn{3}{|c|}{ Studied nurses $(\mathbf{n}=50)$} & \multicolumn{3}{|c|}{ Paired t-test } \\
\hline & $\begin{array}{c}\text { Pre- } \\
\text { program }\end{array}$ & $\begin{array}{c}\text { Post- } \\
\text { program }\end{array}$ & Follow-up & $\begin{array}{l}\text { Pre / } \\
\text { post }\end{array}$ & $\begin{array}{c}\text { Post/ } \\
\text { follow-up }\end{array}$ & $\begin{array}{c}\text { pre/ } \\
\text { follow-up }\end{array}$ \\
\hline \multicolumn{7}{|c|}{ Endotracheal tube suctioning and oral care } \\
\hline Preparation & $35.1 \pm 9.7$ & $83.8 \pm 8.9$ & $81.3 \pm 10.9$ & $<0.0001^{*}$ & 0.211 & $<0.0001 *$ \\
\hline Procedure & $46.3 \pm 6.4$ & $75.2 \pm 4.0$ & $74.2 \pm 4.8$ & $<0.0001^{*}$ & 0.265 & $<0.0001 *$ \\
\hline Post procedure & $54.7 \pm 11.4$ & $92.2 \pm 9.4$ & $89.9 \pm 12.6$ & $<0.0001^{*}$ & 0.329 & $<0.0001 *$ \\
\hline Documentation & $25.0 \pm 0.0$ & $81.5 \pm 10.5$ & $81.5 \pm 10.5$ & $<0.0001^{*}$ & 1.0 & $<0.0001 *$ \\
\hline Total suction \&oral care & $41.5 \pm 5.6$ & $81.7 \pm 4.2$ & $80.1 \pm 5.5$ & $<0.0001^{*}$ & 0.114 & $<0.0001^{*}$ \\
\hline \multicolumn{7}{|c|}{ Endotracheal tube securing, suctioning and ETT cuff measuring } \\
\hline Preparation & $43.3 \pm 10.2$ & $98.7 \pm 2.8$ & $98.7 \pm 2.8$ & $<0.0001^{*}$ & 1.0 & $<0.0001^{*}$ \\
\hline Procedure & $36.6 \pm 4.4$ & $58.1 \pm 2.7$ & $57.4 \pm 3.2$ & $<0.0001^{*}$ & 0.263 & $<0.0001 *$ \\
\hline $\begin{array}{l}\text { Endotracheal tube cuff } \\
\text { pressure measuring } \\
\text { procedure }\end{array}$ & $0.0 \pm 0.0$ & $81.4 \pm 10.1$ & $78.3 \pm 16.1$ & $<0.0001 *$ & 0.252 & $<0.0001^{*}$ \\
\hline Post procedure & $36.6 \pm 6.4$ & $100.0 \pm 0.0$ & $96.0 \pm 6.6$ & $<0.0001^{*}$ & $0.0004^{*}$ & $<0.0001 *$ \\
\hline Documentation & $17.0 \pm 2.3$ & $90.9 \pm 11.3$ & $90.9 \pm 11.3$ & $<0.0001 *$ & 1.0 & $<0.0001^{*}$ \\
\hline Total securing/cuff of ETT & $32.1 \pm 3.0$ & $78.8 \pm 1.9$ & $77.6 \pm 2.7$ & $<0.0001^{*}$ & $0.012^{*}$ & $<0.0001 *$ \\
\hline \multicolumn{7}{|l|}{ Total practice score } \\
\hline & $36.8 \pm 3.1$ & $80.3 \pm 2.2$ & $78.9 \pm 3.2$ & $<0.0001 *$ & $0.012^{*}$ & $<0.0001 *$ \\
\hline
\end{tabular}

*High significant at $\mathbf{P} \leq \mathbf{0 . 0 0 0 1}$ 
Table (3): Frequency and percentage distribution of total scores of nurses' practice regarding suctioning and oral care of patients with endotracheal tube through program phases $(n=50)$

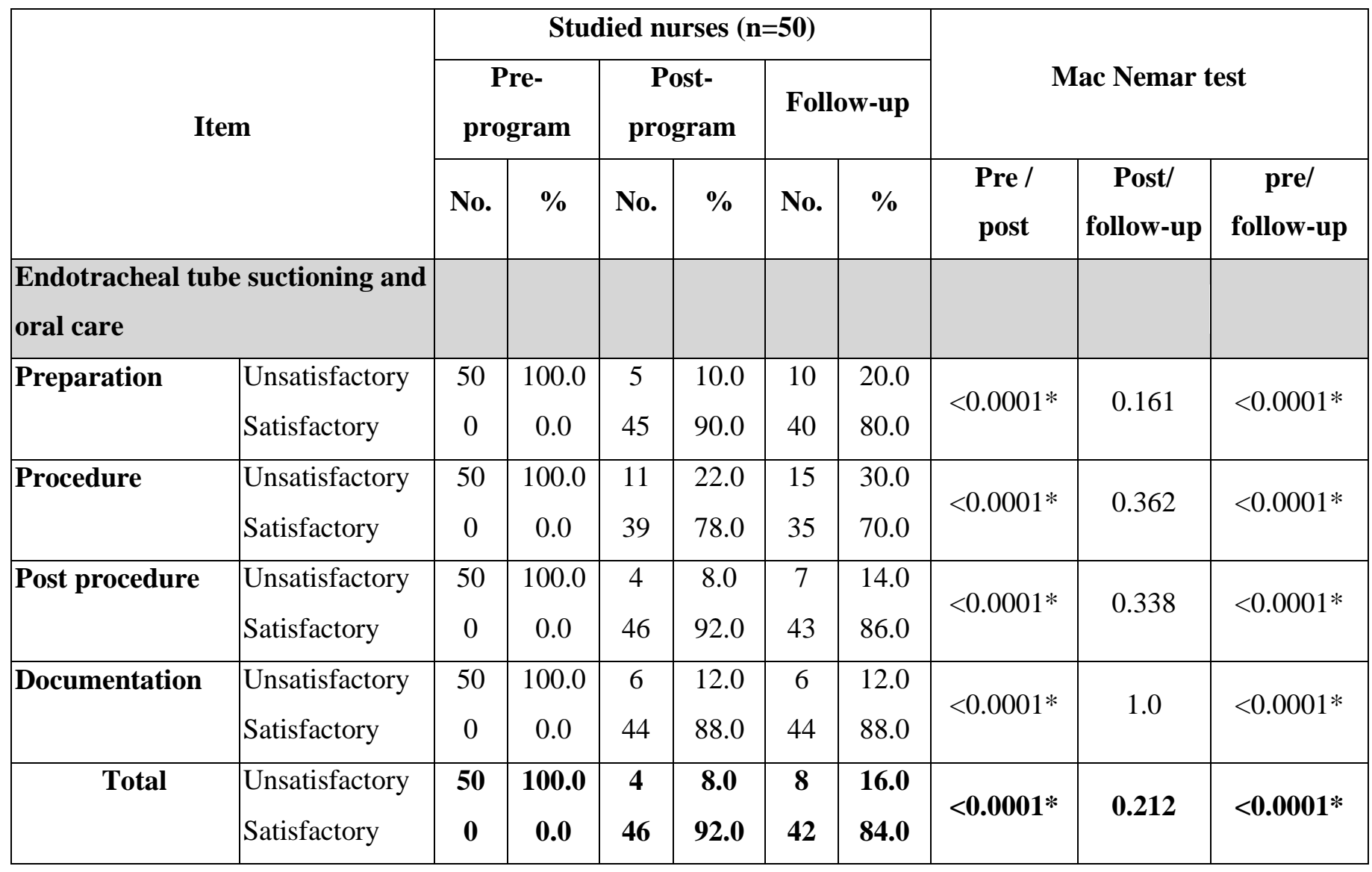

*High significant at $\mathbf{P} \leq \mathbf{0 . 0 0 0 1}$ 
Table 4: Frequency and percentage distribution of total scores of nurses' practice regarding endotracheal tube securing and cuff pressure measuring through program phases $(n=50)$.

\begin{tabular}{|c|c|c|c|c|c|c|c|c|c|c|}
\hline \multirow{3}{*}{\multicolumn{2}{|c|}{ Item }} & \multicolumn{6}{|c|}{ Studied nurses $(\mathrm{n}=50)$} & \multirow{2}{*}{\multicolumn{3}{|c|}{ Mac Nemar test }} \\
\hline & & \multicolumn{2}{|c|}{$\begin{array}{c}\text { Pre- } \\
\text { program }\end{array}$} & \multicolumn{2}{|c|}{$\begin{array}{c}\text { Post- } \\
\text { program }\end{array}$} & \multicolumn{2}{|c|}{ Follow up } & & & \\
\hline & & No. & $\%$ & No. & $\%$ & No. & $\%$ & $\begin{array}{l}\text { Pre / } \\
\text { post }\end{array}$ & $\begin{array}{c}\text { Post/ } \\
\text { follow } \\
\text { up }\end{array}$ & $\begin{array}{c}\text { pre/ } \\
\text { follow up }\end{array}$ \\
\hline \multicolumn{2}{|c|}{$\begin{array}{l}\text { Endotracheal tube securing, } \\
\text { suctioning and cuff measuring }\end{array}$} & & & & & & & & & \\
\hline Preparation & $\begin{array}{l}\text { Unsatisfactory } \\
\text { Satisfactory }\end{array}$ & $\begin{array}{c}50 \\
0 \\
\end{array}$ & $\begin{array}{c}100.0 \\
0.0 \\
\end{array}$ & $\begin{array}{c}0 \\
50 \\
\end{array}$ & $\begin{array}{c}0.0 \\
100.0 \\
\end{array}$ & $\begin{array}{c}0 \\
50 \\
\end{array}$ & $\begin{array}{c}0.0 \\
100.0 \\
\end{array}$ & $<0.0001 *$ & -NA- & $<0.0001 *$ \\
\hline Securing Procedure & $\begin{array}{l}\text { Unsatisfactory } \\
\text { Satisfactory }\end{array}$ & $\begin{array}{c}50 \\
0 \\
\end{array}$ & $\begin{array}{c}100.0 \\
0.0 \\
\end{array}$ & $\begin{array}{c}50 \\
0 \\
\end{array}$ & $\begin{array}{c}100.0 \\
0.0 \\
\end{array}$ & \begin{tabular}{|c|}
50 \\
0 \\
\end{tabular} & $\begin{array}{c}100.0 \\
0.0 \\
\end{array}$ & -NA- & -NA- & -NA- \\
\hline \multirow{2}{*}{$\begin{array}{l}\text { Cuff pressure } \\
\text { measuring } \\
\text { Procedure }\end{array}$} & Unsatisfactory & 50 & 100.0 & 8 & 16.0 & 9 & 18.0 & \multirow{2}{*}{$<0.0001 *$} & \multirow{2}{*}{0.790} & \multirow{2}{*}{$<0.0001 *$} \\
\hline & Satisfactory & 0 & 0.0 & 42 & 84.0 & 41 & 82.0 & & & \\
\hline Post procedure & $\begin{array}{l}\text { Unsatisfactory } \\
\text { Satisfactory }\end{array}$ & $\begin{array}{c}50 \\
0 \\
\end{array}$ & $\begin{array}{c}100.0 \\
0.0\end{array}$ & $\begin{array}{c}0 \\
50\end{array}$ & $\begin{array}{c}0.0 \\
100.0 \\
\end{array}$ & \begin{tabular}{|c|}
2 \\
48 \\
\end{tabular} & $\begin{array}{c}4.0 \\
96.0 \\
\end{array}$ & $<0.0001^{*}$ & 0.495 & $<0.0001 *$ \\
\hline Documentation & $\begin{array}{l}\text { Unsatisfactory } \\
\text { Satisfactory }\end{array}$ & $\begin{array}{c}50 \\
0\end{array}$ & $\begin{array}{c}100.0 \\
0.0\end{array}$ & $\begin{array}{c}5 \\
45\end{array}$ & $\begin{array}{l}10.0 \\
90.0\end{array}$ & \begin{tabular}{c|c}
5 \\
45
\end{tabular} & $\begin{array}{l}10.0 \\
90.0\end{array}$ & $<0.0001 *$ & 1.0 & $<0.0001 *$ \\
\hline Total practices & $\begin{array}{l}\text { Unsatisfactory } \\
\text { Satisfactory }\end{array}$ & $\begin{array}{c}\mathbf{5 0} \\
\mathbf{0}\end{array}$ & $\begin{array}{c}100.0 \\
0.0\end{array}$ & $\begin{array}{c}2 \\
48\end{array}$ & $\begin{array}{c}4.0 \\
96.0\end{array}$ & \begin{tabular}{|c|}
7 \\
43 \\
\end{tabular} & $\begin{array}{l}14.0 \\
86.0\end{array}$ & $<0.0001 *$ & 0.159 & $<0.0001 *$ \\
\hline
\end{tabular}


Table 5: Relation between total mean score of studied nurses' practice related to care of patients with Endotracheal tube throughout the program intervention according to their demographics characteristics $(\mathrm{n}=50)$

\begin{tabular}{|c|c|c|c|c|c|c|c|c|c|c|}
\hline \multirow{3}{*}{ Characteristics } & \multicolumn{10}{|c|}{ Practice score } \\
\hline & \multirow{2}{*}{$\mathbf{n}$} & \multicolumn{3}{|c|}{ Pre-program } & \multicolumn{3}{|c|}{ Post-program } & \multicolumn{3}{|c|}{ Follow-up } \\
\hline & & Mean \pm SD & \multicolumn{2}{|c|}{ Significance } & Mean \pm SD & \multicolumn{2}{|c|}{ Significance } & Mean \pm SD & \multicolumn{2}{|c|}{ Significance } \\
\hline \multicolumn{11}{|c|}{ Age of nurses (years) } \\
\hline Less than 25 & 32 & $29.1 \pm 9.7$ & \multirow[t]{2}{*}{$\mathrm{t}=1.456$} & \multirow{2}{*}{$\mathrm{P}=0.152$} & $97.6 \pm 3.1$ & \multirow[t]{2}{*}{$\mathrm{t}=1.615$} & \multirow{2}{*}{$\mathrm{P}=0.113$} & $94.8 \pm 3.4$ & \multirow[t]{2}{*}{$\mathrm{t}=0.238$} & \multirow{2}{*}{$\mathrm{P}=0.813$} \\
\hline 25 or more & 18 & $25.2 \pm 7.9$ & & & $98.8 \pm 1.4$ & & & $85.0 \pm 3.8$ & & \\
\hline \multicolumn{11}{|l|}{ Sex } \\
\hline Male & 32 & $\mathrm{P}=0.436$ & \multirow[t]{2}{*}{$\mathrm{t}=0.772$} & \multirow{2}{*}{$\mathrm{P}=0.444$} & $80.5 \pm 1.9$ & \multirow[t]{2}{*}{$\mathrm{t}=0.952$} & \multirow{2}{*}{$\mathrm{P}=0.346$} & $79.0 \pm 3.2$ & \multirow[t]{2}{*}{$\mathrm{t}=0.330$} & \multirow{2}{*}{$\mathrm{P}=0.743$} \\
\hline Female & 18 & $\mathrm{P}=0.436$ & & & $79.9 \pm 2.5$ & & & $78.7 \pm 3.2$ & & \\
\hline \multicolumn{11}{|l|}{ Education } \\
\hline Nursing diploma & 19 & $26.9 \pm 7.1$ & \multirow{2}{*}{$\mathrm{t}=0.458$} & \multirow[b]{2}{*}{$\mathrm{P}=0.649$} & $98.9 \pm 1.2$ & \multirow{2}{*}{$\mathrm{t}=1.826$} & \multirow[b]{2}{*}{$\mathrm{P}=0.074$} & $95.4 \pm 3.6$ & \multirow{2}{*}{$\mathrm{t}=0.786$} & \multirow[b]{2}{*}{$\mathrm{P}=0.436$} \\
\hline $\begin{array}{l}\text { Technical } \\
\text { institute }\end{array}$ & 31 & $28.2 \pm 10.3$ & & & $97.5 \pm 3.2$ & & & $94.5 \pm 3.5$ & & \\
\hline \multicolumn{11}{|c|}{ Department of employment } \\
\hline ICU & 20 & $38.5 \pm 2.9$ & \multirow{3}{*}{$\mathrm{F}=5.182$} & & $80.9 \pm 1.9$ & & & $80.5 \pm 2.3$ & & \\
\hline Cardiac ICU & 15 & $35.8 \pm 2.5$ & & D-000* & $79.7 \pm 2.8$ & $\mathrm{~F}=1.565$ & $\mathrm{D}$ - & $77.8 \pm 3.7$ & $\mathrm{~F}=4.734$ & $\mathbf{D}$ \\
\hline $\begin{array}{l}\text { Cardio-thorax } \\
\text { ICU }\end{array}$ & 15 & $35.7 \pm 3.3$ & & & $80.1 \pm 1.7$ & & $1-0.220$ & $78.0 \pm 2.9$ & & $1-0.010$ \\
\hline Duration of nur: & ng e & perience (ye & & & & & & & & \\
\hline$<1$ & 5 & $36.5 \pm 2.7$ & & & $78.8 \pm 2.5$ & & & $77.5 \pm 4.3$ & & \\
\hline $1-<5$ & 21 & $36.6 \pm 2.8$ & $F=0.260$ & $\mathrm{D}-0854$ & $80.7 \pm 2.1$ & $\mathrm{~F}=1.800$ & D- -160 & $79.2 \pm 2.3$ & $\mathrm{~F}=1.003$ & D- 0400 \\
\hline $5-<10$ & 19 & $37.3 \pm 3.1$ & & & $79.9 \pm 2.1$ & & & $78.5 \pm 3.6$ & & \\
\hline 10 or more & 5 & $36.4 \pm 5.4$ & & & $81.6 \pm 1.8$ & & & $80.7 \pm 2.9$ & & \\
\hline Receiving traini & g col & rses of ET t & & & & & & & & \\
\hline Yes & 19 & $37.3 \pm 2.9$ & $\mathrm{t}=0.732$ & & $80.4 \pm 2.1$ & $\mathrm{t}=0.340$ & & $79.4 \pm 3.2$ & $\mathrm{t}=0.878$ & \\
\hline No & 31 & $36.6 \pm 3.3$ & & & $80.2 \pm 2.2$ & & & $78.6 \pm 3.1$ & & \\
\hline
\end{tabular}


Table 6: Frequency and percentage distribution of nurses' opinions about nursing educational program $(\mathrm{n}=50)$

\begin{tabular}{|c|c|c|c|}
\hline \multicolumn{2}{|l|}{ Item } & \multicolumn{2}{|c|}{$\begin{array}{l}\text { Studied nurses } \\
\qquad(\mathbf{n}=\mathbf{5 0})\end{array}$} \\
\hline & & \multirow{2}{*}{ No. } & \multirow{2}{*}{$\%$} \\
\hline Educational program & & & \\
\hline \multirow{4}{*}{$\begin{array}{l}\text { 1. Topic of the } \\
\text { program }\end{array}$} & Excellent & 42 & 84.0 \\
\hline & Very good & 4 & 8.0 \\
\hline & Good & 3 & 6.0 \\
\hline & Pass & 1 & 2.0 \\
\hline 2. Scientific content & Excellent & 50 & 100.0 \\
\hline \multirow{4}{*}{$\begin{array}{l}\text { 3. Benefits from } \\
\text { program }\end{array}$} & Excellent & 41 & 82.0 \\
\hline & Very good & 6 & 12.0 \\
\hline & Good & 2 & 4.0 \\
\hline & Need to clarify & 1 & 2.0 \\
\hline \multirow{4}{*}{ 4. Time of program } & Excellent & 11 & 22.0 \\
\hline & Very good & 18 & 36.0 \\
\hline & Good & 11 & 22.0 \\
\hline & Pass & 10 & 20.0 \\
\hline \multirow{4}{*}{ 5. Goals achieved } & Excellent & 38 & 76.0 \\
\hline & Very good & 9 & 18.0 \\
\hline & Good & 2 & 4.0 \\
\hline & Need to clarify & & \\
\hline \multirow{4}{*}{$\begin{array}{l}\text { 6. Clearance of } \\
\text { program }\end{array}$} & Excellent & 17 & 34.0 \\
\hline & Very good & 18 & 36.0 \\
\hline & Good & 10 & 20.0 \\
\hline & Pass & 5 & 10.0 \\
\hline
\end{tabular}


Table 7: Frequency and percentage distribution of nurses' opinions methods of teaching \& media nursing educational program $(n=50)$

\begin{tabular}{|c|c|c|c|}
\hline \multicolumn{2}{|c|}{ Item } & \multicolumn{2}{|c|}{$\begin{array}{l}\text { Studied nurses } \\
\qquad(\mathbf{n}=\mathbf{5 0})\end{array}$} \\
\hline & & No. & $\%$ \\
\hline \multicolumn{4}{|l|}{ Teaching method \& media } \\
\hline \multirow{4}{*}{ 1. Lectures } & Excellent & 20 & 40.0 \\
\hline & Very good & 26 & 52.0 \\
\hline & good & 4 & 8.0 \\
\hline & pass & 0 & 0.0 \\
\hline \multirow{4}{*}{ 2. Discussions } & Excellent & 13 & 26.0 \\
\hline & Very good & 33 & 66.0 \\
\hline & good & 4 & 8.0 \\
\hline & pass & 0 & 0.0 \\
\hline 3. Posters & Excellent & 50 & 100.0 \\
\hline 4. Booklets & Excellent & 50 & 100.0 \\
\hline
\end{tabular}

\section{DISCUSSION:}

The period of post-intubation is a vital and urgent phase for airway management in Intensive Care and Emergency Units. Patients necessitating emergency airway management often have restricted physiologic reverse, and in spite of successful endotracheal tube placement, there were accompanying a lot of complications. These must be immediately predictable and noted (Kovacs \& Law, 2011) .

In this study, the total mean nurses' practice score regarding ETT care in pre-program were $36.8 \pm 3.1$ and increase in post program to $80.3 \pm 2.2$ while, practice scores slightly decrease to $78.9 \pm 3.2$ in follow -up program. This might be due to absence of training program, booklet and standard for care inside each unit in pre program and after implementing program nurses' practice increase and slightly decrease regarding lack of supplies requiring for performing procedure in their unit. This agreement with (Aysha et al., 2016) who illustrated that the mean scores of nurse's performance of protocol of care strategies, in (phase I) were $223.57 \pm 41.42$ and increased to 
$629.20 \pm 11.21$ in phase II ,while the mean performance score decreased slightly to $567.65 \pm 8.86$ in phase III.

In this study regarding nurses' practice for ETT suctioning and oral care, the total mean score was significantly higher in post program than pre program implementation. This might be due to success of program, may attribute to the fact that procedure were practiced under supervision and guidance of researcher. This result in the same line with (Majeed, 2013) who found that nurses' performance was improved in post-program than pre -program implementation.

Also, the total mean nurses' practice score regarding ETT suction and oral care was increase through post /follow -up program than the pre- program, In my point of view, the ongoing and continuous education programs for nurses were important in sustaining good oral care and suctioning performed among ETT patients. This agreement with (Zaiton \& Elhanafy, 2015) who reported in the study about "Impact of implementation nursing guidelines on minimizing ventilator associated pneumonia among intensive care patients" that total mean nurses' practice score regarding ETT suctioning was upgraded in post nursing guidelines than pre nursing guidelines.

This study results, also agreement with (Farsi et al., 2015) who illustrated in the study about" Effect of clinical audit process on level of endotracheal suctioning skill in nurses and anesthesia technicians working in intensive care units" that there were a highly statistically significant differences in the total mean score regarding endotracheal suction practice was increase in post intervention phase than preintevention phase.

As regarding nurses' performance for endotracheal suctioning in pre-program implementation, it was showed that nearly to one third of studied nurses was satisfactory practice. This might be due to lack of supervision for nurses' performance regarding endotracheal tube suctioning and oral care in their units. This in agreement with (Varghese \& Moly, 2016) who noticed that less than one quarter of studied nurses had satisfactory practice regarding ETT suctioning. 
As regarding to ETT securing, there was a highly statistically significant difference in total scores of studied nurses' practice between pre/post and pre/follow -up program implementation phases. This might be due to continuous training and supervision and guidance from the researcher improves nurses' practice regarding endotracheal securing. This in agreement with (Lois Krug et al., 2016) who illustrated in the study about "Changing Endotracheal Tube Taping Practice: An Evidence-based Practice Project" that the anesthesia providers involved in the study have improved their insights about the taping performance since rise in their responsiveness and information of the taping performance.

In the present study, the majority of nurses were a significant difference between the mean score of pre- implementing and post- implementing practices scores regarding the endotracheal tube cuff pressure procedure. This might be due to informing nurses about the importance of endotracheal tube cuff pressure monitoring to avoid and reduce occurrence of complication associated with cuff over inflation or deflation. This was in agreement with (Penitenti et al., 2010) who found in the study about"Cuff pressure control in intensive care unit: training effects Adult Intensive Care Unit of Hospital Geral de Itapecerica da Serra - São Paulo (SP), Brazil " that the improvement in the practice level after training program intervention than practice level in pre -training program intervention a about endotracheal tube cuff monitoring. Also, this result in agreement with (Maboudi et al., 2013) who emphasized in the study about "Accuracy of endotracheal tube cuff pressure adjustment by fingertip palpation after training of intensive care unit nurses. Iranian Red Crescent Medical Journal" that appropriate inflation of the endotracheal tube cuff during mechanical ventilation is very important to avoid ETT complications and confirming adequate ventilation.

The majority of nurses had unsatisfactory practice regarding measuring endotracheal tube cuff ( ETTC) pressure at pre-program. This might be due to inaccessibility of cuff inflator device in the hospitals also, inadequate knowledge among staff nurses about ETTC procedure monitoring and lack of training program and supervision. This was in agreement with (Seliman et al., 2011) who illustrated in the study about "Effect of implementing nursing guidelines for tube feeding on the occurrence of aspiration among critically ill patients" that all critical care nurses had 
unsatisfactory practice regarding check endotracheal tube cuff pressure before nasogastric tube feeding.

Regarding nurses' reevaluation for patients after suctioning and oral care procedure, it was showed that all nurses had unsatisfactory practice in pre-program phase, while the post program, there was a statistical significant improvement in practice. This in agreement with (Jansson et al., 2013a) who indicated in the study about " Evaluation of endotracheal-suctioning practices of critical-care nurses-An observational correlation study" Journal of Nursing Education and Practice, that all critical-care nurses had un satisfactory practice in post endotracheal-suctioning assessment.

In the present study, there was a highly statistically significant difference in their practice regarding ETT care in pre /post-program implementations. This might be related to emphasize the importance of training and reinforcing the correct technique as had been done. This was in agreement with (Haza'a et al., 2015) who notified that there was a statistically significant difference in nurses' performance in comparison between pre /post- implementation regarding endotracheal tube care.

Regarding to documentation after ETT care in pre implementation program phase, the majority of nurses had unsatisfactory practice for documentation measures. This might be due to ignorance of nurses about importance of documentation notes after performing ETT care. This was in agreement with ( $\underline{\text { Cloete, 2010) }}$ who recommended in the study about "An Evaluation of Documentation of Endotracheal Intubation in Cape Town Emergency Centres. University of Cape Town" that developed template designs for implementation the documentation quality in the emergency centers.

As regarding, documentation practice after performing ETT care, there was an improvement in nurses' practice in post program than pre program implementation. This might be related to inform nurses that documentation protects and safe her from falling in mistakes. This result was in agreement with (Winton et al., 2008) who found in the study about " Improving documentation of endotracheal intubation in an adult emergency department, Emergency medicine Australasia" that the nurses improved documentation of endotracheal tube care after implementing the program. 
The study revealed that the mean post-implementation knowledge and practice score of nursing personnel regarding endotracheal suctioning was significantly higher than the mean pre-implementation knowledge and practice score. This finding attributed that the education program, booklet and direct supervision become effective and improve nurse performance regarding endotracheal tube care. This was in agreement with (Sharma et al., 2014) who stated that the protocol was effective in improving knowledge and practices of nursing personnel regarding the endotracheal suctioning.

Moreover, this results in agreement with (Subramanian et al., 2013) in the study about "Impact of education on ventilator-associated pneumonia in the intensive care unit. Singapore medical journal" emphasized that nurse-led education on VAP and ventilator care bundle (VCB) significantly increased knowledge and compliance with VCB practices among ICU nurses, and was associated with a reduction in the incidence of VAP among intubated and mechanically ventilated ICU patients.

In the present study, there was no significant relation between years of experience and the post-test practice score. This might be due to years of experience not affected on nurses' practice. This was in agreement with (Ansari et al., 2012) who showed that there was no significant relation between years of experience and nurses' practice. in the same time disagreed with (Majeed, 2013) who illustrated that there were a significant relation in the nurses' performance and their years of experience for post-test practice score. As well as, this was disagreement with $(\underline{\boldsymbol{A b d}}$ $\underline{E L-A z i z, 2014}$ ) who stated that nurses with more years of experience in the ICU performed oral care practices more frequently for intubated patients.

\section{CONCLUSION:}

According to the result of this study, some important factors could be concluded:

- The post mean practice scores of nurses exposed to an educational program about endotracheal tube care was higher than their pre mean practice scores. 


\section{RECOMMENDATIONS:}

From the foregoing conclusion, the following recommendations are suggested:

Upgrading nurses' practice about caring of patients with endotracheal tube through:

- Encouraging nurses to attend, seminars, conferences and workshops about endotracheal tube and the care providing for patient with endotracheal tube.

- Developing follow -up courses and in-service training programs should be conducted to maintain efficient performance for nurses previously trained on care of patients with endotracheal tube.

- Developing a system of periodical evaluation for nurses to determine strategies of upgrading their knowledge and enhancing their practice.

- Encouraging training courses about endotracheal tube which should be mandatory for newly employed nurses.

\section{REFERENCES:}

Abd EL-Aziz, M.A., (2014): Effect of Educational Program On Nurses Knowledge and Skills about Oral care for Traumatized Patients. AAMJ, 12(1):2547.

Aitken, L., Marshall, A., and Chaboyer, W., (2016): ACCCN's Critical Care Nursing. $3^{\text {rd }}$ ed., Elsevier - Health Sciences Division,Australia. P474.

Ansari, A., Masoudi Alavi, N., Adib-Hajbagheri, M., and Afazel, M., (2012): The gap between knowledge and practice in standard endo-tracheal suctioning of ICU nurses, Shahid Beheshti Hospital. Journal of Critical Care Nursing, 5(13) 7176.

\section{American Nurses Association (2016):}

http://www.nursingworld.org/MainMenuCategories/ThePracticeofProfessionalNur sing/NursingEducation/ContinuingEducationforNurses.

Aysha, Z.M.S., El-Din, S.M.A., Attia, N.R., and Ibrahim, M. (2016):Efficacy of Implementing Nursing Care Protocol on the Incidence of Ventilator Associated 
Pneumonia in Intensive Care Unit at Tanta Emergency Hospital. Journal of American Science, 12(2) : 40-52.

Bahar, I., Elay, G., Coskun, R., Gundogan, K., Guven, M., and Sungur, M., (2015): Complications of Endotracheal Intubation in the Intensive Care Unit: A Single-center Experience after Training. Erciyes Med J Erciyes Tip Dergisi/Erciyes Medical Journal, 37(4): 133-137.

Cherry, B., and Jacob, S.R., (2016): Contemporary Nursing: Issues, Trends, \& Management. $7^{\text {th }}$ ed., Mosby, USA.Pp:40-65.

Cloete, P.G., (2010): An Evaluation of Documentation of Endotracheal Intubation in Cape Town Emergency Centres. Master thesis Faculty of Health Sciences,University of Cape Town.Pp:30-34.

De Jong, A., Jung, B., and Jaber, S., (2014): Intubation in the ICU: we could improve our practice. Critical care 18 (1):1-7.

DeLaune, S.C., and Ladner, P.K., (2011): Fundamentals of nursing, $4^{\text {th }}$ ed., standards \& practice. Delmar, Clifton Park, N.Y. Pp:400-405.

Dennison, R.D. (2013): PASS CCRN®! $4^{\text {th }}$ ed., Elsevier Health Sciences;USA. p.290.

Farsi, Z., Kalroozi, F., Nezamzadeh, M., and Rashidfar, S. (2015): Effect of clinical audit process on level of endotracheal suctioning skill in nurses and anesthesia technicians working in intensive care units, 2(2): 76-83.

Haza'a, A.N.A.M., Ibrahim, H.A., Mohammed, M.A., and AbdEl-Aziz, M.A. (2015): Impact of Educational Training Program on Nurse's Performance for Patient Undergoing Endotracheal Tube at Assiut University Hospital. Un published Master Thesis, Faculty of Nursing, Assiut University. Pp71-72.

Jansson, M., Ala-Kokko, T., Ylipalosaari, P., and Kyngäs, H. (2013a): Evaluation of endotracheal-suctioning practices of critical-care nurses-An observational correlation study. Journal of Nursing Education and Practice, 3(7): 99-105.

Kovacs, G., and Law, J.A. (2011): Airway Management in Emergencies. People's Medical Publishing House-USA;2nd ed;PP:223-224. 
Lewis, S.L., Dirksen, S.R., Heitkemper, M.M., and Bucher, L. (2014): Medical-Surgical Nursing: Assessment and Management of Clinical Problems, Single Volume. $9^{\text {th }}$ ed., Elsevier Health Sciences, Canada, P.459.

Lois Krug, D., Machan, M.D., and Villalba, J. (2016): Changing Endotracheal Tube Taping Practice: An Evidence-based Practice Project. AANA Journal, 84(4): 251- 261

Lynn, P., (2015a): Skill checklists for Taylor's clinical nursing skills : a nursing process approach. $4^{\text {th }}$ ed., Wolters Kluwer, Philadelphia, Pp:720-740.

Maboudi, A., Abtahi, H., Hosseini, M., Tamadon, A., and Safavi, E. (2013). Accuracy of endotracheal tube cuff pressure adjustment by fingertip palpation after training of intensive care unit nurses. Iranian Red Crescent Medical Journal, 15(5): 381-384.

Majeed, S.M.A. (2013): Effectiveness of planned teaching programme on knowledge and practice of endotracheal suctioning among staff nurses in selected hospitals of Mangalore. Asian Journal of Nursing Education and Research, 3(4): 243-247.

Morton, P.G., and Fontaine, D.K., (2013): Critical Care Nursing: A Holistic Approach. $10^{\text {th }}$ ed., Wolters Kluwer Health/Lippincott Williams \& Wilkins China. p.514.

Omera MA., Abdel Aziz MM., Abo Atta BA \& Ali., MA (2013): Assessment of Nurses' knowledge and practice regarding care for patients with endotracheal tube. Unpublished Master Thesis Degree, Faculty of Nursing, Suez Canal University.P:3, 50.

Penitenti, R., M., Vilches, J.I., Oliveira, J.S., Mizohata, M.G., Correa, D.I., Alonso, T.R., Mathiazzi, I.C., and Testa, R.S. (2010): Cuff pressure control in intensive care unit: training effects (Controle da pressão do cuff na unidade terapia intensiva: efeitos do treinamento). Revista Brasileira de terapia intensiva, 22 (2):192-195. 
Perry, A.G., Potter, P.A., and Ostendorf, W. (2014): Clinical Nursing Skills and Techniques, $8^{\text {th }}$ ed., Elsevier Health Sciences, Phaledphia, Ch, 25, Pp: 626643.

Proehl, J.A., (2009): Emergency nursing procedures. 4th ed., Saunders Elsevier, St. Louis, Mo. USA, Pp: 27- 57.

Seliman, A.M., El-Soussi, A.H., Sultan, M.A., and Othman, S.Y. (2011): Effect of Implementing Nursing Guidelines for Tube Feeding on the Occurrence of Aspiration among Critically Ill Patients. Nature and Science, 9(11): 164-175.

Samuelson, K.A.M., (2011): Adult intensive care patients' perception of endotracheal tube-related discomforts: A prospective evaluation. YMHL Heart \& Lung - The Journal of Acute and Critical Care, 40(1): 49-55.

Sharma, S., Sarin, J., and Kaur Bala, G. (2014): Effectiveness of "endotracheal suctioning protocol" in terms of knowledge and practices of nursing personnel. Nursing and Midwifery Research Journal, 10(2): 47-60.

Subramanian, P., Choy, K.L., Gobal, S.V., Mansor, M., Ng, K.H. (2013): Impact of education on ventilator-associated pneumonia in the intensive care unit. Singapore medical journal, 54(5): 281-284.

Varghese, S.T., and Moly, K., (2016): Exploratory study on the knowledge and skill of critical care nurses on endotracheal suctioning. The Journal of National Accreditation Board for Hospitals \& Healthcare Providers, 3(1): 13-19.

Winton, J., Celenza, A., and Jackson, T. (2008): Improving documentation of endotracheal intubation in an adult emergency department. Emergency medicine Australasia : EMA, 20(6): 488-493.

Zaiton, H.I., and Elhanafy, E.Y. (2015): Impact of Implementation Nursing Guidelines on Minimizing Ventilator Associated Pneumonia among Intensive Care Patients. Advances in Life Science and Technology (29): 2015: 40-51. 
